\title{
Time-Dependent Effects of Chitosan on Dentin Structures
}

\author{
Polliana Vilaça SILVA \\ Débora Fernandes Costa GUEDES \\ Jesus Djalma PÉCORA \\ Antonio Miranda da CRUZ-FILHO. \\ Department of Restorative Dentistry, Ribeirão Preto Dental School, \\ USP - University of São Paulo, Ribeirão Preto, São Paulo, Brazil
}

\begin{abstract}
Complete debridement with smear layer removal are essential measures for achieving a successful outcome of root canal treatment. The aim of this study was to evaluate the effects of chitosan at different concentrations on the removal of the smear layer and on dentin structure after 3 and 5 min of application. Twelve recently extracted maxillary canine teeth were instrumented using the crown-down technique and irrigated with $1 \%$ sodium hypochlorite. The specimens were distributed according to the time and concentration of the final irrigating solution: G1: $0.1 \%$ chitosan for $3 \mathrm{~min}$; $\mathrm{G} 2: 0.2 \%$ chitosan for $3 \mathrm{~min}$; G3: $0.37 \%$ chitosan for 3 min; G4: $0.1 \%$ chitosan for $5 \mathrm{~min}$; G5: $0.2 \%$ chitosan for $5 \mathrm{~min}$; G6: 0.37\% chitosan for $5 \mathrm{~min}$. All samples were prepared for SEM analysis. G1 exhibited removal of the smear layer, but not the smear plugs. G2 showed visible and open tubules with slight erosion of the peritubular dentin. Cleaning in G3 was similar to that in G2, however, the erosive effect was greater. There was expansion of the diameter of the tubules in G4; and in G5 and G6, there was severe erosion with deterioration of dentin surface. In conclusion, $0.2 \%$ chitosan for 3 min appeared to be efficient for removing the smear layer, causing little erosion of dentin.
\end{abstract}

Key Words: smear layer, chitosan, chelators, root canal treatment.

\section{INTRODUCTION}

The presence of smear layer in the root canal favors the adhesion and colonization of microorganisms (1), in addition to impairing the action of disinfectant solutions (2) and the penetration of sealing cements through the dentinal tubules (3). For the effective removal of organic and inorganic components from the smear layer, irrigation with EDTA combined with different concentrations of sodium hypochlorite $(\mathrm{NaOCl})$ has been recommended (4). However, the search for solutions more biocompatible than EDTA, in an attempt to minimize damage to the periapical tissues, has appeared with increasing frequency in the literature (5). However, EDTA can be erosive to dentin, depending on its concentration and application time (6). Sen et al. (7) observed erosion of the root dentin after using EDTA in concentrations of 1, 5, 10 and $15 \%$ for $1 \mathrm{~min}$. Another disadvantage is that EDTA is considered a pollutant, since this substance is not found originally in nature (4).
Chitosan is a natural polysaccharide, coming from the deacetylation of chitin, which is obtained from the shells of crabs and shrimp (8). This polysaccharide has a molecular weight ranging from $1,000,000$ to $3,000,000$ and properties of biocompatibility, biodegradability, bioadhesion and atoxicity to the human body (9). Having an acid $\mathrm{pH}$, it shows remarkable chelating capacity for different metal ions, which justifies its use in various sectors of industry (8). Chitin, after cellulose, is the most abundant substance in nature, which makes its use very interesting from the ecological point of view as well as economically viable (10). The aim of this study was to evaluate the effects of chitosan, at different concentrations and application times on smear layer removal and dentin structure.

\section{MATERIAL AND METHODS}

Twelve freshly extracted human maxillary canine teeth were used in this study. Access to the pulp chamber

Correspondence: Prof. Dr. Antonio M. Cruz-Filho, Departamento de Odontologia Restauradora, Faculdade de Odontologia de Ribeirão Preto, USP, Avenida do Café, S/N, 14040-904 Ribeirão Preto, SP, Brasil. Tel: +55-16-3602-4792. Fax: +55-16-3633-0999. e-mail: cruz@forp.usp.br 
was achieved using spherical diamond-tipped drills attached to a high-speed motor under water cooling. A standard flare was produced by inserting 45/.06, 35/.06 and 20/.06 La Axxess drills (Sybronendo Corporation, West Collins, Orange, CA, USA). The working length (WL) was established using a \#10 K-file (Dentsply Ind. e Com. Ltda., Petrópolis, RJ, Brazil) introduced into the root canal of each tooth up to the point that it was visible at the apex and then retracted $1 \mathrm{~mm}$. The anatomic diameter (AD) was determined by introducing K-type manual files of successively increasing diameters, until one of them met resistance upon being retracted from the pre-established WL. The crown-down technique was performed using nickel-titanium instruments (Quantec; Sybronendo Corporation), up to four instruments greater than that which determined the AD. With each exchange of instruments, the root canal received $1 \mathrm{~mL}$ of $1 \% \mathrm{NaOCl}$.

For preparation of the chelating solutions, different amounts of chitosan (Acros Organics, Geel, Belgium; degree of deacetylation $>90 \%$ ) weighed in grams $(0.1,0.2$ and 0.37$)$ were placed in $200 \mathrm{~mL}$ beakers and $100 \mathrm{~mL}$ of $1 \%$ acetic acid were added. The mixtures were blended using a magnetic stirrer for approximately
$2 \mathrm{~h}$ until obtaining crystalline homogeneous solutions with $3.2 \mathrm{pH}$.

The specimens were distributed into 6 groups: G1: $0.1 \%$ chitosan for $3 \mathrm{~min}$; $\mathrm{G} 2$ : $0.2 \%$ chitosan for $3 \mathrm{~min}$; G3: $0.37 \%$ chitosan for $3 \mathrm{~min}$; G4: $0.1 \%$ chitosan for 5 min; G5: $0.2 \%$ chitosan for $5 \mathrm{~min}$; G6: $0.37 \%$ chitosan for $5 \mathrm{~min}$. Each specimen received $5 \mathrm{~mL}$ of chitosan and in the end, all the samples were irrigated with $10 \mathrm{~mL}$ of $1 \% \mathrm{NaOCl}$. The specimens were sectioned longitudinally using diamond disks attached to the low-rotation motor. The hemisection that best represented the root canal was prepared for scanning electron microscopy (SEM) analysis.

Thirty-six SEM micrographs of the middle third of the root were obtained using a scanning electron microscope (JSM5410; JEOL, Tokyo, Japan) with $\times 1,000,2,000$ and 5,000 magnifications.

\section{RESULTS}

In the group treated with $0.1 \%$ chitosan for 3 $\min (\mathrm{G} 1)$, removal of the entire smear layer from dentin surface was observed (Fig. 1A). However, at the highest magnification $(\times 5,000)$, the presence of smear plugs and
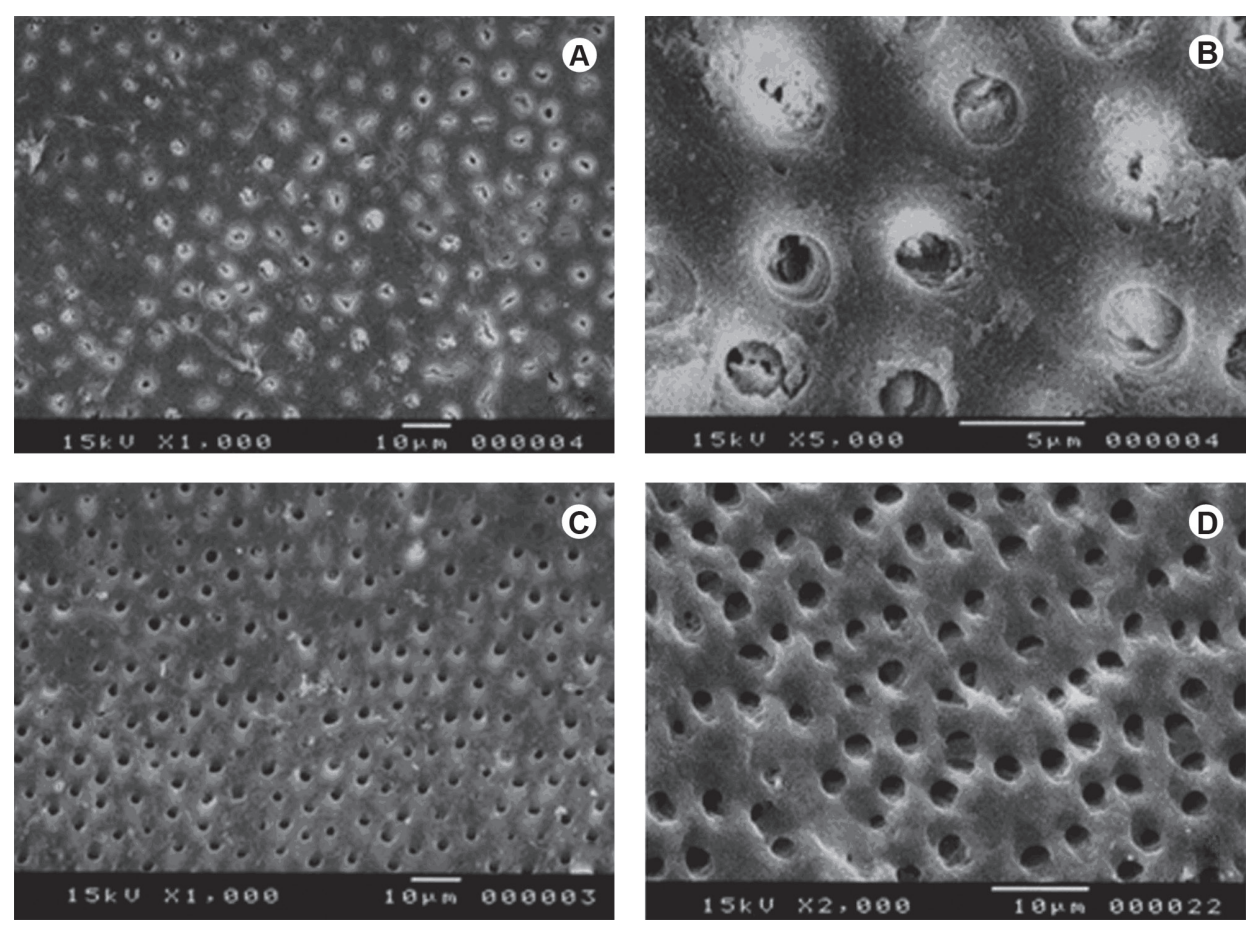

Figure 1. Composite figure of SEM micrographs. A: Complete removal of the smear layer $(\mathrm{G} 1$ at $\times 1,000)$. B: Presence of smear plug in the tubules and slight peritubular erosion $(\mathrm{G} 1$ at $\times 5,000)$. C: Surface of the specimens from $\mathrm{G} 2$, totally clear of smear layer $(\times 1,000)$. D: Dentinal tubules clearly visible and open (G2 at $\times 2,000)$. 
slight peritubular erosion in part of the dentinal tubules was verified (Fig. 1B). In G2, complete removal of the smear layer with all the tubule openings was clearly visible (Fig. 1C), without the presence of the smear plug, but with slight erosive effect on the peritubular dentin (Fig. 1D). Increasing the concentration of chitosan to $0.37 \%$ for $3 \mathrm{~min}$ (G3) promoted removal of the smear layer similar to $\mathrm{G} 2$; however, there was a greater erosive effect on the peritubular dentin, in addition to erosion of the tubular dentin (Fig. 2A). To investigate the prolonged effect of chitosan, the middle third of the root canals in G4, G5 and G6 was treated with the chelating agent for 5 min. In G4, expansion of the tubular dentin was noticed in most of the dentinal tubules (Fig. 2B); while in G5 and G6, the erosive effect was severe, with exaggerated increase of the tubular diameter and extensive destruction of the intertubular dentin, promoting the combination of tubular openings and deterioration of the dentin surface (Fig. 2C and 2D).

\section{DISCUSSION}

Studies have shown the importance of using
EDTA for the removal of the inorganic components of the smear layer (7). However, despite being efficient in removing the smear layer, EDTA has an erosive effect on dentin (7) and attacks the periapical tissues (11) in addition to being considered an environmental pollutant (4). To deal with organic structures, previous studies have sought for weaker and more biocompatible acids than $\operatorname{EDTA}(5,12)$.

Chitosan is a natural polysaccharide, biodegradable, biocompatible with human cells (9) and with a high chelating capacity (8). This study compared its capacity to remove the smear layer as well as its structural effects on dentin, using different concentrations of the substance and application times. It is known that the efficiency of a chelating agent depends on several factors (application time, $\mathrm{pH}$, concentration of the solution and amount of solution) $(6,13,14)$. Thus, in the present study, the volume of chitosan ( $\mathrm{pH} 3.2)$ used in the final irrigation was standardized at $5 \mathrm{~mL}$ for 3 and $5 \mathrm{~min}$. The amount of solution and application time were based on the studies of Spanó et al. (4) and MachadoSilveiro et al. (12), respectively. Machado-Silveiro et al. (12) studied the capacity of 3 different solutions for
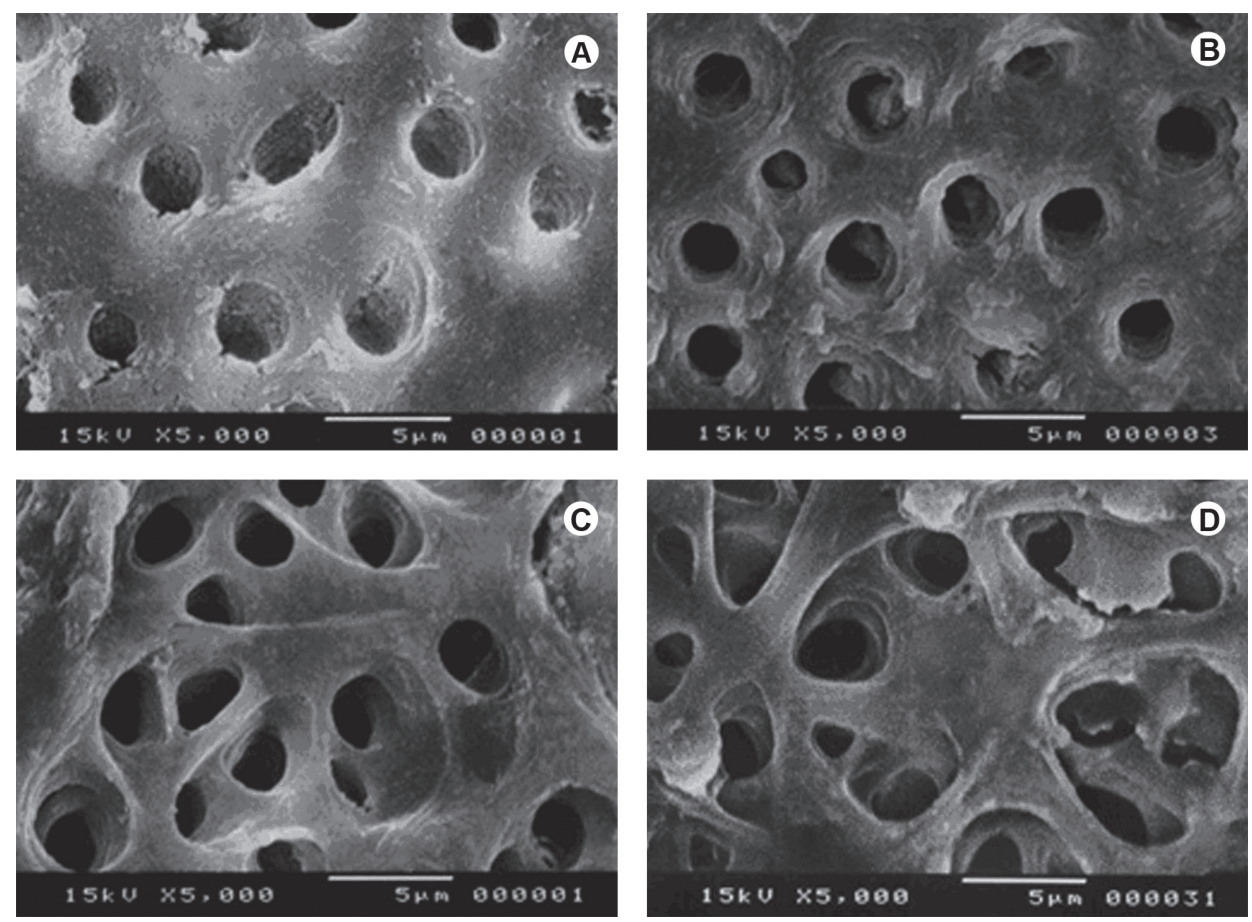

Figure 2. Composite figure of SEM micrographs. A: Slight erosive effect on the peritubular and tubular dentin $(\mathrm{G} 3$ at $\times 5,000)$. B: Specimens from G4 with expansion of the tubular diameter $(\times 5,000)$. C: Excessive erosive effect: note that the edges of the tubules are undefined and the surface layer is damaged in depth (G5 at $\times 5,000)$. D: Severe erosive effect with wide tubular opening and deterioration of dentin surface $(\mathrm{G} 6$ at $\times 5,000)$. 
removing calcium ions from the root dentin at 5, 10 and $15 \mathrm{~min}$. Those authors concluded that $17 \%$ EDTA and $10 \%$ sodium citrate, used for more than $5 \mathrm{~min}$, did not increase the capacity for calcium removal. The 0.1 , 0.2 and $0.37 \%$ solutions of chitosan, used for $5 \mathrm{~min}$, promoted exaggerated expansion of the tubular diameter, degrading dentin as the concentration increased.

The deterioration of dentin surface, verified in the combinations of concentration/time of application, may have been fostered by the prior irrigation with $\mathrm{NaOCl}$ during the biomechanical preparation. The organic portion of dentin is subjected to the action of $\mathrm{NaOCl}$, which alters the collagen matrix. This effect, combined with the demineralizing action of the chelating agent, most probably caused the progressive dissolution of dentin (15). The excessive erosive effect verified for the solutions in the 5-min period suggested reducing the application time, maintaining the three concentrations. Among the solutions applied for $3 \mathrm{~min}$, the $0.2 \%$ chitosan was the most efficient for removing the smear layer and smear plug with minimal erosive effect. This result suggests the use of $0.2 \%$ chitosan as a possible alternative to replace EDTA. A recent study (16) demonstrated that the $0.2 \%$ chitosan applied for 3 min on root dentin presented a similar cleaning ability as $15 \%$ EDTA and $10 \%$ citric acid.

Studies have highlighted the disadvantages of using EDTA at high concentrations. The combination of EDTA and $\mathrm{NaOCl}$ caused progressive dissolution of dentin at the expense of peritubular and intertubular areas $(6,11,15)$. Hu et al. (17) reported that rough surfaces could be a clinical benefit, as in the case of micromechanical bonding of adhesive materials that need irregularities on the surface. However, rough surfaces will promote bacterial adhesion, which might lead to plaque formation.

Chitosan, even at the lowest concentration, was capable of adequately remove the smear layer from the dentin surface. Previous studies have shown that

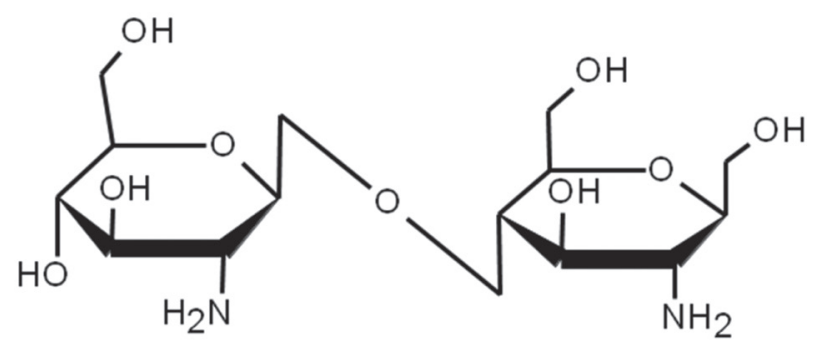

Figure 3. Dimer of chitin. solutions with considerably higher concentrations than $0.2 \%$ chitosan and with longer application times than the 3 min used in this study $(18,19)$ are necessary for removing this layer. Spanó et al. (4) evaluated the cleaning capacity of $15 \%$ EDTA, $10 \%$ citric acid, 10\% sodium citrate, apple vinegar, 5\% acetic acid and 5\% malic acid. Those authors used $5 \mathrm{~mL}$ of the test solution for $5 \mathrm{~min}$ and found that only $15 \%$ EDTA and $10 \%$ citric acid removed the smear layer from the middle third of the root canal. The relationship between the concentration of the chelating agent and the application time seems to be important since high-concentration solutions applied during a long period, cause roughness of dentin surface. Çalt and Serper (6) observed that 17\% EDTA applied for $10 \mathrm{~min}$ for smear layer removal caused an excessive erosive effect with dissolution of the peritubular and intertubular dentin, and concluded that, in order to avoid dentin erosion, EDTA should not be applied for more than $1 \mathrm{~min}$.

Currently, two theories explain the possible chelating mechanism of chitosan. One theory, known as the bridge model, states that two or more amino groups of a chain of chitosan bind to the same metal ion (20). The second theory supports that only one amino group of the structure of the substance is involved in the binding, which is the metal ion "anchored" to the amino group (21). The chitosan polymer is formed by a chain composed of several dimers of chitin. Similar to the EDTA molecule, the chitin dimer (Fig. 3) shows two nitrogen atoms with pairs of free electrons responsible for the ionic interaction between the metal and the chelating agent. In an acid medium, the amino groups present in the bipolymer are protonated, resulting in an overall position charge $\left(-\mathrm{NH}^{3+}\right)$. This form is responsible for the attraction to other molecules in order for adsorption to occur (22). The formation of complexes between chitosan and metal ions most probably is due to the mechanisms of adsorption, ion exchange and chelation. The type of interaction that occurs depends on the involved ions, the chemical structure of chitosan and the $\mathrm{pH}$ of the solution (23). Pimenta et al. (24) reported that the $0.2 \%$ chitosan solution ( $\mathrm{pH} 3.2$ ) has a capacity of reducing dentin microhardness similar to that of $15 \%$ EDTA (pH 7.25).

The clinical use of new solutions must be preceded by laboratory studies that investigate the benefits and consequences to the human organism. Thus, other researches must be conducted in order to learn even more about the chemical and biological properties 
of chitosan. Based on the results of the present study, it may be concluded that $0.2 \%$ chitosan for 3 min removed the smear layer adequately and caused less erosion than EDTA.

\section{RESUMO}

Completo debridamento dos canais radiculares com a remoção da smear layer são medidas essenciais no sucesso do tratamento endodôntico. O objetivo deste estudo foi avaliar os efeitos da quitosana, em diferentes concentrações, na remoção da smear layer e na estrutura da dentina, após 3 e 5 min de aplicação. Doze dentes caninos superiores, recém extraídos, foram instrumentados pela técnica crown-down e irrigados com hipoclorito de sódio 1\%. Os espécimes foram distribuídos em seis grupos conforme o tempo e a concentração da solução irrigante final: $\mathrm{G} 1$ : quitosana $0,1 \%$ por $3 \mathrm{~min}$; G2: quitosana $0,2 \%$ por $3 \mathrm{~min}$; G3: quitosana $0,37 \%$ por $3 \mathrm{~min}$; G4: quitosana $0,1 \%$ por $5 \mathrm{~min}$; G5: quitosana $0,2 \%$ por 5 min; G6: quitosana $0,37 \%$ por $5 \mathrm{~min}$. Todas as amostras foram preparadas para avaliação em MEV. Os resultados mostraram que o G1 apresentou remoção da smear layer, mas não da smear plug. O G2 mostrou túbulos visíveis e abertos com ligeira erosão da dentina peritubular. A limpeza no G3 foi semelhante à do G2, no entanto, o efeito erosivo foi maior. No G4 houve ampliação do diâmetro dos túbulos e no G5 e G6, severa erosão com deterioração da superfície dentinária. Concluiu-se que a quitosana $0,2 \%$ por 3 min foi eficiente na remoção da smear layer, ocasionando pequena erosão.

\section{REFERENCES}

1. Sen BH, Chugal NM, Liu H, Fleischmann J. A new method for studying the adhesion of Candida albicans to dentin in the presence or absence of smear layer. Oral Surg Oral Med Oral Pathol Oral Radiol Endod 2003;96:201-206.

2. Haapasalo M, Orstavik D. In vitro infection and disinfection of dentinal tubules. J Dent Res 1987;66:1375-1379.

3. Kouvas V, Liolios E, Vassiliadis L, Parissis-Messimeris S, Boutsioukis A. Influence of smear layer on depth of penetration of three endodontic sealers: a SEM study. Endod Dent Traumatol 1998;14:191-195.

4. Spanó JCE, Silva RG, Guedes DFC, Sousa-Neto MD, Estrela C, Pécora JD. Atomic absorption spectrometry and scanning electron microscopy evaluation of concentration of calcium ions and smear layer removal with root canal chelators. J Endod 2009;35:727-730.

5. Haznedaroglu F. Efficacy of various concentrations of citric acid at different $\mathrm{pH}$ values for smear layer removal. Oral Surg Oral Med Oral Pathol Oral Radiol Endod 2003;96:340-344.

6. Çalt S, Serper A. Time-dependent effects of EDTA on dentin structures. J Endod 2002;28:17-19.

7. Sen BH, Ertürk Ö, Pişkin B. The effect of different concentrations of EDTA on instrumented root canal walls. Oral Surg Oral Med Oral Pathol Oral Radiol Endod 2009;108:622-627.
8. Kurita K. Chemistry and application of chitin and chitosan. Polyme Degrad Stabil 1998;59:117-120.

9. Akncbay H, Senel S, Ay ZY. Application of chitosan gel in the treatment of chronic periodontitis. J Biomed Mater Res B Appl Biomater 2007;80:290-296.

10. Peter MG. Applications and environmental aspects of chitin and chitosan. J Macromol Sci A 1995;32:629-640.

11. Serper A, Çalt S, Dogan AL, Guc D, Ozçelik B, Kuraner T. Comparison of the cytotoxic effects and smear layer removing capacity of oxidative potential water, $\mathrm{NaOCl}$ and EDTA. J Oral Sci 2001;43:233-238.

12. Machado-Silveiro LF, González-López S, González-Rodríguez MP. Decalcification of root canal dentine by citric acid, EDTA and sodium citrate. Int Endod J 2004;37:365-369.

13. Hülsmann $M$, Heckendorff $M$, Lennon A. Chelating agents in root canal treatment: mode of action and indications for their use. Int Endod J 2003;36:810-830.

14. Cruz-Filho AM, Silva RG, Pécora JD. Acción del EDTAC en la microdureza de la dentina radicular en diferentes tiempos de aplicación. Rev Odont Fed Lati Amer (FOLA) 1996;2:82-90.

15. Baumgartner JC, Mader CL. A scanning electron microscopic evaluation of four root canal irrigation regimens. J Endod 1987; 13:147-157.

16. Silva PV, Guedes DFC, Nakad FV, Pécora JD, Cruz-Filho AM. Chitosan: a new solution for removal of smear layer after root canal instrumentation. Int Endod J 2012. [Epub ahead of print. DOI: 10.1111/j.1365-2591.2012.02119.x.].

17. Hu X, Ling J, Gao Y. Effects of irrigation solutions on dentin wettability and roughness. J Endod 2010;36:1064-1067.

18. Scelza MF, Pierro V, Scelza P, Pereira M. Effect of three different time periods of irrigation with EDTA-T, EDTA, and citric acid on smear layer removal. Oral. Surg. Oral Med. Oral Pathol Oral Radiol Endod 2004;98:499-503.

19. Mozayeni MA, Javaheri GH, Poorroosta P, Ashari MA, Javaheri HH. Effect of $17 \%$ EDTA and MTAD on intracanal smear layer removal: A scanning electron microscopic study. Aust Endod J 2007;35:13-17.

20. Blair HS, Ho TC. Studies in the adsorption and diffusion of ions in chitosan. J Chem Technol Biotechnol 1981;31:6-10.

21. Domard A. pH and c.d. measurements on a fully deacetylated chitosan: application to CuII-polymer interactions. Int J Biol Macromol 1987;9:98-104.

22. Shahidi F, Arachchi JKV, You JJ. Food applications of chitin and chitosan. Trends Food Sci Technol 1999;10:37.

23. Rhazi M, Desbrières J, Tolaimate A, Rinaudo M, Vottero P, Alagui A, et al.. Influence of the nature of the metal ions on the complexation with chitosan. Application to the treatment of liquid waste. Eur Polym J 2002;38:1523-1530.

24. Pimenta JA, Zaparolli D, Pécora JD, Cruz-Filho AM. Chitosan: effect of a new chelating agent on the microhardness of root dentin. Braz Dent J 2012;23:212-217.

Received May 5, 2012 Accepted September 25, 2012 